\title{
The economy of smiles: affect, labour and the contemporary deserving
}

\section{poor}

This paper examines the affective dimensions of new forms of informal entrepreneurial work carried out in spaces of unemployment. Situating the analysis within contemporary scholarship on deservingness and on affect and labour, I shed light on the forms of entrepreneurial labour that rely upon affect-driven economies of exchange underpinned by moral judgements of deservingness, value and worth. In particular, this paper draws on a multi-city (Melbourne, London, San Francisco) study of homeless street press sellers (The Big Issue and Street Sheet) to explore the ways in which contemporary practices of charity and care are carried out through individualised market-place exchanges. Sellers' accounts of their work reveal how smiling and being (or looking) happy is a performative expectation that must be managed in the face of poverty and precarity.

KEYWORDS: affect, deservingness, homelessness, entrepreneurialism, unemployment

The notion of affect, and specifically affective labour, has growing prominence in sociological scholarship. It is used to point to the ways in which different forms of post-Fordist labour rely on the production of affectivities; the ways in which feelings, embodiments, moods, emotions and relationships are central to ways in which work (paid and unpaid) is performed and experienced. In particular, a range of sociologists use notions of affect to understand new forms of creative, cultural, media, feminised and service labour underpinned by conditions of pracarity (e.g. Taylor, 2015; Gill, 2007; Gill \& Pratt, 2008; Gray et al 2017). In this paper, I turn to a consideration of the affective dimensions of labour in precarious, entrepreneurial (and highly marginalised and informal) forms of labour. These, in other words, are entrepreneurial workers who are "not the

This is the author manuscript accepted for publication and has undergone full peer review but has not been through the copyediting, typesetting, pagination and proofreading process, which may lead to differences between this version and the Version of record. Please cite this article as doi:10.1111/ 1468-4446.12350. 
potential drivers of future prosperity but the marginal figures excluded from it" (Taylor, 2015, 185).

I take as my example the proliferating practice of selling homeless street papers (such as The Big Issue or Street Sheet) on city streets across the globe by the homeless, poor and long-term unemployed. As the analysis presented here demonstrates, this form of labour is imbued with affectivity in ways that are tied to the meaning and value of the commodity and exchange cultures. In this work charity is remade into individualised consumer exchanges, requiring sellers to perform deservingness alongside 'saleability'- a smiling, welcoming disposition. I suggest that the affectivities produced in this form of labour are sutured onto the commodity and the moment of exchange. In other words, the affective labour of these highly precarious and marginalised workers is knitted to the commodity: a magazine or paper defined by its purpose as providing legal income for the homeless and long-term unemployed.

I start by outlining how contemporary discourses of deservingness are expressed through entrepreneurial ideals, placing enterprising capacities as a principal marker of worth and value. I demonstrate how entrepreneurial initiatives constitute an important site of deserving employment created in response to unemployment and disadvantage. Second, I set out how homeless street press is connected to wider trends towards entrepreneurial understandings of deservingness and poverty alleviation. Third, I turn to consider how affective labour is connected to entrepreneurialism within contemporary capitalism, in which enterprise culture underpins the conditions of un/employment. Lastly, drawing on extensive ethnographic research across Australia, England and the US, I examine how homeless street press sellers 
engage and perform their entrepreneurial selves through the production of affectivities. This research demonstrates how smiling and being (or looking) happy is a key performative expectation of this work and central to the potential to sales. Smiling is integral to feelings of success and accomplishment, however it is also a form of affective labour that comes with its challenges, particularly in the context of precarity and poverty.

\section{The new deservingness: entrepreneurialism}

In the contemporary context deservingness hovers like an ash cloud permeating public and policy debates surrounding welfare, unemployment and poverty, discursively carried out in moralised registers of race, sexuality, gender and class (e.g. Nagel \& Ehrkamp, 2016; Beechey, 2016). For the unemployed - those who are seen as 'not pulling their weight' and who appear to exist outside of the social relations governed by the work ethic and capital accrual - perceptions of laziness, uselessness, ungratefulness, and cultural excess encircle (see Skeggs \& Loveday, 2012). Such perceptions are, as Fraser and Gordon (1994) suggest, connected to a fear of 'dependency' in which the poor and unemployed are demonised for their apparent reliance on welfare and charity. In this way, deservingness indicates the long-standing past and present judgements of worth surrounding the lives of those who receive care, welfare and charity (see Peel, 2012; see also Seabrook, 2013). Such judgements reveal underlying tensions within capitalism surrounding idleness and productivity. The need to address the perennial 'problem' of the so-called 'idle unemployed' has plagued capitalist governance, and long prompted a range of responses in an attempt to curb its effects (see Author; Grundy \& Rudman, 2016). 
Such dynamics are being created anew at a time of significant change in the meaning and practice of welfare and charity, in which entrepreneurialism and enterprise are key indicators of deservingness. Writing in the late 1980s Nikolas Rose (1989) described the 'enterprising self' as interconnected with the emergence of neoliberalism, and the transcendent notion of the autonomous rational self (see also Du Gay, 1996; Dean, 1995). Now, entrepreneurialism is ubiquitous within public policy (see Author; Kelly, 2013): to be entrepreneurial is not reserved for venture capitalists, but for us all. Entrepreneurialism has come to denote a positive zest for life: a taken-for-granted rule-for-life, involving "energy, initiative, self-reliance and personal responsibility" (du Gay, 1996: 60; see also Rose, 1992). This has produced the emergence of mass entrepreneurship, in which the spirit of enterprise is the medium by which we live and think (Dardot \& Laval, 2014).

Thus, whilst entrepreneurialism and the enterprise of self-invention is often viewed as a middle-class pursuit (Scharff, 2016), the embrace of enterprise as a policy answer to poverty and unemployment extends its reach as a governing concept and practice. A key dimension of this contemporary entrepreneurialism is the eventful character of contemporary unemployment. As Lisa Adkin's work demonstrates, unemployment is a highly productive field of activity $(2012 ; 2017)$. The presumption of 'unproductivity' in the lives of the unemployed is problematized by the imperatives for job seekers to engage in 'productive' (work and education) schemes (Adkins, 2017). Through workfare, training, counselling, cv-building sessions and so on, unemployment has become "a highly eventful state" (Adkins, 2012: 635; see e.g. Morris \& Wilson, 2014). In this context, there is widespread take-up of the language and practices of 
enterprise in 'poverty areas'. Beyond government initiatives and public policy, from microfinance and microcredit in the development sector to social enterprise in the welfare sector, entrepreneurialism is now routinely touted as offering dignified pathways out of poverty (see Roy, 2010; Signalla \& Carney, 2012; Author e.g. HM Government, 2011; Commonwealth of Australia, 2014).

\section{Homeless street press: purchasing poverty}

Importantly, the emergence of contemporary entrepreneurialism is linked to a long history of self-help initiatives. Throughout the 1970s and 1980s, in the context of (and response to) a heavily bureaucratised welfare field, a diverse range of self-organised groups aimed to provide support and opportunities for social participation (Author). A key historical example of this is homeless street press, first established across the US in the 1970s and 1980s. Homeless street press had the intention of providing a form of legal income for the homeless (as opposed to begging which was and is often illegal); advertising relevant support and activist services to the homeless; and spreading news and analysis of homelessness (see e.g. Danky \& Wiagand 1998; Green 1998).

In many ways, past and present homeless street press are representative of the entrepreneurial activities and informal economies created out of necessity in the face of adversity and poverty (see Gowan, 2010; Gaber 1994). In recent years, however, they have evolved to have a more explicit relationship to practices of enterprise. Specifically, one of the most globally recognisable social enterprises- The Big Issue - is a homeless street press. In the 1990s, having seen a New York homeless street press, businessperson Gordon Roddick partnered with John Bird to transpose and develop the practices of homeless street press 
with a business imperative (Swithinbank, 2001; see also Author). Starting first in London, but then expanding globally, the result of this partnership - The Big

Issue - is explicit in its enterprising underpinnings and desires.

Indeed, The Big Issue is part of a growing social enterprise sector that provides a range of employment and employment-like opportunities for the unemployed. Social enterprise is a diverse field of practice, that at its heart attempts to provide market-based business solutions to social and environmental 'problems' (see e.g. Teasdale, 2010). Other employment-based examples include celebrity chef Jamie Oliver's restaurant Fifteen (see Kelly \& Harrison, 2009), and STREAT café in Melbourne, Australia. These initiatives exist on the edges of formal employment and unemployment. In the case of the The Big Issue, sellers (or 'vendors') engage in highly precarious self-employment, based on individual sales, as discussed further below.

There are two key aspects of this approach. First, is the underpinning assumption of the power of personal responsibility and empowerment enacted through the creation of work-based initiatives for unemployed and marginalised (see Author; see Kelly \& Harrison, 2009). Second, is that consumers purchase a commodity or service direct from the people who are considered to benefit from their consumption: the unemployed and disadvantaged. For The Big Issue many sellers are homeless, others are long term unemployed or with profound health problems or disabilities which make mainstream or formal employment out of reach. Thus, social enterprise represents a new form of entrepreneurialism expressed through the premise of the worth and value of individual citizens buying a product as an act of care and consumption (see Sigalla \& Carney, 2012; Lindemann, 2006). 
These proliferating practices of entrepreneurialism have become inextricably tied to contemporary understandings of poverty and possible solutions to it, representing a "new entanglement of business and welfare, and a new iterative focus on individual agency" (Author). They also muddy the distinction between public and private, as whilst social enterprises are not formally connected to the state, many do receive grants and support from government (see e.g. Centre for Charitable Giving and Philanthropy, 2012). These are market-based initiatives that place significant faith in the market and the capacity of the circulation of capital to respond to key social problems (ibid). Their focus on individual self-help and entrepreneurial zest for life can individualize the effects of - and responses to - inequality (see Gordon, 2013; Author). Deservingness therefore becomes articulated through practices of success demonstrated through personal growth, persistence and goal-setting in the face of entrenched and structural inequality.

Nevertheless, it is important to note that not all homeless street press are social enterprises. Globally, across different cities, presses take a range of approaches from business-oriented social enterprise magazines to grassroots campaign newspapers. For instance, Street Sheet in San Francisco is far more connected to the political cultures of grassroots activism, and rejects the marketbased entrepreneurialism offered by the social enterprise model (see Author).

Yet, across these differences, homeless street press are common in their provision of legal income for those who are otherwise excluded from the labour market (see Author). This is a highly precarious form of legitimate income, existing on the margins of economic legitimacy (Cockburn, 2014). 
Thus, across organisational differences, homeless street press is a form of labour with complex links to the contemporary dynamics of deservingness. Homeless street press have effectively created an exchange market, in which social action on poverty and homelessness is tied to consuming a commodity (see Cockburn, 2014; Zizek 2009). It is by all accounts a 'step up' from begging, and thereby is accompanied with notions of deservingness as well as points of distinction. Lindemann suggests homeless street press presents stigma in a form of purchasable souvenir - a souvenir in the sense of offering 'a piece of the Other' (2007). Despite the diversity of organisational ethos, the work practices created by homeless street press provide a legitimate form of income that remains wedded to the poverty (and judged deservingness) of the seller. It creates a marketised, direct and individual medium of charity, in which affect is central.

\section{Affective entrepreneurialism}

At the centre of homeless street press is the moment of exchange between buyer and seller. Personalised exchanges between buyer and seller cultivates particular affectivities premised on 'doing good' and 'caring' on the part of the buyer (see Hibbert, Hogg \& Quinn, 2005; Lindemann, 2006) and ‘being productive' on the part of the seller (as explored below). As Llewellyn \& Burrow's (2008) research on the moments of exchange in selling The Big Issue also demonstrates, sales are crafted through moments of recognition between seller and possible buyer. The need for this moment of exchange (the moment of income generation), engenders the practice of affective labour, and a form of affective entrepreneurialism. 
Notions of affect and affective labour signal an attempt to understand how labour can be "corporeal and affective, in the sense that its products are intangible: a feeling of ease, well-being, satisfaction, excitement, passion-even a sense of connectedness or community" (Hardt, 1999). It indicates the broad labour of sociality; the 'affective labour' which produces "social networks, forms of community, biopower" (Hartdt, 1999: 96). It also indicates the blurred lines between work and life, whereby affective and aesthetic capacities - such as the capacity to create a welcoming 'vibe' - are brought into work practices (De Giorgi, 2006). Focus is placed on the ways in which communicative, caring, and social activities are encapsulated within waged work, as well as the 'capitalisation' of leisure and social networks to enhance personal value and improve networks (that may be later exploited for waged work) (see De Giorgi, 2006).

Importantly, as Angela McRobbie (2010) points out, the conceptual development of affective labour has clear (and frustratingly underacknowledged) correspondences with long-standing feminist critiques of the sociology of work and the affectivities of gendered labour (see also Weeks, 2007; Federici, 2008). This includes, Arlie Hochschild's demonstration of the management and use of emotions within the gendered economy. Examining the boundary between work and self in this work Hochschild (1983: 89-90) asks: When worked-up warmth becomes an instrument of service work, what can a person learn about herself from her feelings? And when a worker abandons her work smile, what kind of tie remains between her smile and her self? 
Taking the case of flight attendants, Hochschild reveals how feelings are managed so as to ensure workers perform warmth and a happy personalised service (see also more recently, Williams, 2003).

Extending Hochschild's work many have already identified how affect is central in the aestheticized performances required for interactive sales work (e.g. Entwistle \& Wissinger, 2006; Tyler, 2012). As is the focus of this paper, for those engaged in enterprising sales-based work on the margins of employment affective labour is intensified due to the relational and moralised economy within which it operates. For instance, and as noted above, existing research indicates that the purchase of fair trade and social enterprise products as well as microfinance initiatives are premised by a reflexive and moralised act of individualised care (e.g. Dolan, 2007; Hibbert et al, 2005; Mittelman \& RojasMendez, 2013; see also Barnett et al 2005; Li, 2017). In other words, the commodity exchange process marks out the affective dimensions of consumption and care. The sale of the product allows judgments of deservingness and an act of care to be bestowed by the purchaser on the seller. This enterprising work is therefore both affective and precarious. It offers some possibility of income, though this is tied to a morally charged and insecure market in which workers' affective representations of themselves as worthy, is as - if not more - important than the product, service, or investment opportunity they are offering, as I now explore.

\section{Smiles: performing entrepreneurialism}

In what follows I draw on a large multi-city ethnographic research project on the working lives of homeless street press sellers. The research spans Street Sheet, 
an activist grass roots newspaper in San Francisco, and The Big Issue, one of the most prominent global social enterprises, in London and Melbourne. These three cities were chosen in part because of their historical significance in relation to homeless street press. Street Sheet predates The Big Issue and lays claim to being the longest continuing operating homeless street press. London was the site of the founding of The Big Issue in 1991, and Melbourne was one of the first international expansions of The Big Issue beyond the UK in 1996. In addition, taking a trans-national approach allows the comparative investigation of the global phenomenon of homeless street press along side the operation of informal economies and contemporary articulations of deservingness.

However, this comparison is not intended to imply simple cultural, social or political correspondences: each country and city has very different governance frameworks and welfare policies. Nevertheless, as major cities in the global 'North' there are parallel developments across London, San Francisco and Melbourne, including the 're-discovery' of poverty in the 1970s and 1980s

(Hobsbawm, 1994) and the consequent development of dedicated homelessness service fields and policy developments (Minnery and Greenhalgh 2003). In all three cities the significant presence of homelessness remains a stubborn 'policy problem', and in all cities begging is an offence thus making homeless street press one of the few routes to legitimate income for the homeless and marginalised.

Therefore, researching across these cities brings insight into the diverse transnational experiences of homelessness and work in 'advanced capitalist' contexts, which are both contingent to each city whilst also integrally connected to global contexts. Indeed, it is important to note that despite the significant 
organisational and city-based differences between The Big Issue and Street Sheet (see Author), the analysis presented here reveals striking commonalities: sellers in all three cities experienced similar imperatives to cultivate 'happy' 'smiling' selling techniques in order to attract sales, in spite of differences in the political and enterprising ethos of Street Sheet and The Big Issue.

Methodologically the project took an ethnographic approach, which

focused on understanding everyday lived experiences. Centring the importance of the 'everyday' this project sought to develop in-depth knowledge of the routine work experiences of homeless street sellers, and their perspectives on this (see Highmore, 2002; Back, 2015). The methodological focus on the everyday also meant that this research does not attempt to uncover past trauma as the authentic representation of poverty (see Peel, 2007). Nor was the presumption made that I - as researcher - could somehow unearth sellers' 'authentic' selves through their interviews (see Author). Rather, methodological focus was given to the rhythms, routines, feelings, and associations made in relation to working life.

Moreover this research did not attempt to document homeless street press sellers lives as somehow extraordinary to capitalist relations but as enmeshed within the cultures of capitalist inequality that create the conditions of their working lives (see Author). Thus, interviews focused on everyday experiences of work, feelings and understandings about work, the balancing of work and leisure and personal time, the perceptions and experiences of learning and self-development through work, and hopes and desires for the future. Reflecting this methodological position, in the analysis that follows considerable space is given to the accounts told by sellers themselves in their own words. 
The bulk of the research was carried out in Melbourne, where forty sellers (and one ex-seller) were interviewed - many of who participated in ongoing interviews over the course of approximately eighteen months. I spent a month in both San Francisco and London and in each city twelve sellers were interviewed. Sellers were recruited from city streets, and in some cases from the offices of the homeless street press. I encountered, and recruited a significantly lower number of women sellers for the research, and whilst these numbers appear to reflect a gendered quality to this work, they cannot be taken as representative given the qualitative nature of the project (11 in Melbourne, 3 in San Francisco and 1 in London). Across all cities, time was spent with sellers whilst they worked in order to develop a closer understanding of the dynamics of this work practice. This time varied depending on the sellers and their wishes. Some were happy for me to tag along for hours - and in some cases days, others preferred me to observe their work sitting at a distance, whilst others selected just to be interviewed. This research provides the first in-depth account of the everyday experiences of these highly marginalised entrepreneurial workers. In what follows, I focus on one aspect of this larger project by analysing the affective dimensions of the work, exploring sellers' attempts to craft deserving and entrepreneurial 'happy' dispositions First, I explore how smiling factors as a core affective component of the exchange economy created by homeless street press. Second, I examine what I describe as the 'shadow worlds of smiling': the experiences of frustration, sadness and loneliness that sit underneath the surface performance of happiness that sellers do in order to attract and make sales. To protect the anonymity of sellers pseudonyms are used throughout. 


\section{Smiling and entrepreneurial labour: 'he's selling himself!'}

In the case of homeless street press, the task of selling the papers or magazines is as much a task of selling yourself. This was how a group of three men put it when talking to me at the offices of San Francisco's Street Sheet. One of the three is a Street Sheet seller, whilst the other two are ex- sellers who now work within the Coalition on Homelessness (the grassroots activist and advocacy organisation, which edits and distributes the Street Sheet). All are currently homeless. We were in the midst of talking about good and bad sale days when the name of a particular seller came up - Ben Andrews.

Allan (40s): A lot of the vendors take less [Street Sheet] papers and make more money. The person we're talking about, Ben Andrews, he'll pick up papers once, maybe twice a week, if that. And he usually gets at least five dollars or more for each one he sells.

Guy (30s): He’s selling Ben Andrews.

Researcher: He's good at chatting?

Max (50s): Exactly. He’s selling more than the Street Sheet, he's selling himself.

Researcher: He's as good salesman?

Max: He works the tourists. He carries [Street] Sheets with him everywhere and I mean he just picks them out of the crowd.

Guy: He’s well dressed, you know what I mean? He’s articulate.

This discussion of Ben Andrews highlights the complex politics and ethics - performative, visual, and affective - that underpin homeless street press work. Allan, Guy and Max pinpoint the embodied and affective sales strategies that characterises selling homeless street press. To bring oneself into the practice of work - to sell oneself as Ben Andrews does - is fundamentally an affective and entrepreneurial act, requiring the surfacing and performance of the self in commodified ways (see Murtola, 2014). This marks a form of affective labour - a 
'feminisation' of labour - in which "emotional, non-verbal communication

becomes a part of the relation between capital and labour" (Morini \& Fumagilli,

2010: 242).

Of course, all had different approaches to this sales work: some loudly

called out into the street; others made up songs and rhymes; whilst others

preferred to stay quiet - searching the faces of people passing by as they stood or

sat waiting for a sale. There are undeniable gendered dynamics to this affective labour. In all three cities, the vast majority of the women I spoke to preferred more 'quiet' approaches, and many talked about being constantly aware of their personal safety (or, more precisely, lack of) as they worked the city streets (see Author). The most financially successful sellers - those who managed to (in busy hours on busy days) break close to the equivalent of the minimum wage - were charismatic men who (whilst often standing still) would use their bodies to follow the flow of pedestrians, directly target potential buyers, 'banter' about current events and the weather, and in some cases unabashedly flirt with women passing by.

Nonetheless, from quiet standing to raucous calling out the importance of smiling emerged again and again. The act of smiling connected sellers' diverse sales approaches across the three cities, marking a strikingly common means by which sellers understood themselves as engaging in deserving and worthy work. For instance, when I ask Ryan (Melbourne, 44 years old) what makes a good Big Issue seller, he doesn't hesitate:

A smile - that goes a long way - a smile. My wife said- 'Oh you've got a beautiful smile.' And I just thought, 'Oh yeah, you're my wife- you're just saying that because you're my wife.' But then two girls walk past and they come up and say, 'Oh we had to buy off you 
because you've got such a beautiful smile!' And I was like, 'You are kidding me!' I went back and told [my wife] and she said, 'See, I told ya!'

Ryan's smile - a connection between himself and his wife - is brought into his work: his smile is central to moment of commodity exchange. In this way, the affectivity of smiling is woven into the value of the magazine as it forms the basis by which exchanges occur.

Similarly, Stacey (Melbourne, 33 years old) cultivates her sales strategies by combining smiling with singing and dancing. She explained that in order to attract sales she dances and sings whilst listening to songs through her headphones.
Researcher: What kind of responses do you get?
Stacey: I get lots of people smiling and some people give me little tips here and there, saying, 'That's for doing what you're doing.'
Researcher: So you reckon it helps sales?
Stacey: It does actually, I'm the only one that does it that I know of. I haven't heard anyone else that's done it. [...] I do get some stares like 'What are you doing, you look strange!?'
Researcher: Does that bother you?
Stacey: No, no, I just smile and keep going. I don't care. I ignore it. You get people that will come past and look funny at you but you ignore them 'cause if you let it get to you, you can't work. You've got to pretend they're not there.

Smiling here is a deliberative performative practice. Combined with singing and dancing it represents Stacey's attempt to craft a unique selling technique that will help her 'stand out' from other sellers. Like many other sellers, as I discuss below, it is also part of her strategy to cope with possible negative judgements of her work practice. 
A key theme to emerge from sellers' accounts is the use of smiles as a means to demonstrate worthiness and deservingness as workers, as opposed to

beggars. This is how Jan (48 years old, Melbourne) - a 'quiet seller' - put it: I feel like a beggar when I am spruiking [calling out to sell the magazine]. So it's not a style I really go with. But sometimes on a really slow day I might, but you know, like today, I will stand out there with my magazine and I will just stand there and be very patient and wait there for people to come to me. [...] Sometimes I try and catch people's eye, and try smiling at people- that goes a long way. Because if you're frowning you're not going to attract any people, you're just going to look like another beggar.

In London, James (58 years old) also talked about smiling as connected to distinguishing himself as not a beggar, and as a part of the sociality of his work:

We've got a sign underneath The Big Issue badge - 'I am a seller not a beggar'. And one of the no-nos is you don't stop a man and say, 'Excuse me have you got any small change?' That's begging in my eyes and that's a no. 'Excuse me sir/young lady would you like to buy a copy of The Big Issue on this beautiful day. Puts a smile on your face guaranteed,' and then they break into a smile and I say 'It's working already!' And the amount of people that actually come back and buy a copy of the magazine, honestly it's a great experience.

As a highly informal work practice, which is often perceived to be a form of begging and 'not a real job', the question of respectability and deservingness is important for sellers. In this sense, as for Jan and James, smiling becomes linked to deservingness: a performed affectivity that suggests worthiness and an enterprising spirit, carried out in the hope of sales and as a mechanism to be distinguished as not begging. For these sellers the exchange of smiles - the moment of affective recognition - constitutes this as work rather than begging. Here, the social relationships (even momentary) and affective entrepreneurial exchanges between seller and buyer mark this practice as deserving (and, for 
James, enjoyable) work. These practices of distinction are particularly

significant for the many sellers whose homeless street press work marks an

important biographical moment of moving from beggar to worker, as I explore

further elsewhere (Author).

Unsurprisingly, sellers across the three cities understood well the need to affectively connect with buyers in order to secure income success. Here their performance and practice of smiling is a part of the entrepreneurial basis of selling homeless street press. Kyle (San Francisco, 48 years old), for example, reflected:

Kyle: I'm always smiling because you know you've got to smile because people like that. They don't like people to be grumpy. You don't be rude to them Researcher: Is that hard sometimes when people are rude to you...? Kyle: No, I don't—if they're rude I just walk off and say, 'Thank you sir you have a good day', or 'Thank you ma'am, you have a good day, catch you next time.'

Smiling is, therefore, an affectivity expressed in order to convey warmth, genuineness, and conviviality, but always in relation to the performative requirements of the work. Kyle's consistent smiling, politeness and happiness is central to his sales strategy, as he later told me, 'You never know who will turn back around and buy off you'. Thus, smiling is also connected to the precarious/perennial character of this work: anyone and everyone passing by could be a future customer. Kyle's reflections are important given the organisational differences between Street Sheet in San Francisco and The Big Issue in London and Melbourne. As an activist paper, many sellers in San Francisco did not view selling as work, but as a legitimate and legal means to beg (or panhandle) (see Author). However, whilst not necessarily viewed as work, selling Street Sheet 
was still marked in distinction from begging, and as requiring the constant management and performance of positive affectivity. Smiles, therefore, are part of the symbolic affective economies of exchange that occur in homeless street press work. They are a means for sellers to engage with buyers (or potential buyers), even in the most fleeting moments, and are connected to the coping strategies of working in public and to the sense of enjoyment that some sellers experience.

\section{Shadow worlds of smiling: acting happy}

As the discussion above hints at, the use of smiles makes the work manageable and is connected to feelings of worth and achievement, yet it also has a shadow side. Feeling the requirement to perform happiness, warmth and deservingness came with its toll for many sellers. Again and again sellers talked in one breath about smiling as essential to attracting sales and feeling good, and then in the next breath the difficulties and struggle to maintain that. As mentioned above, one affective dimension of this work practice is the ways in which sellers need to commodify themselves in order to attract sales. For some, the need to demonstrate the value and worth of themselves resulted in creative and enterprising practices that came with their toll. It is here that the shadow world of smiling emerges: sellers develop performances of deserving affectivities whilst also managing the toll such performances and of long-term poverty.

A key aspect of this is maintaining welcoming and happy performances in the face of ongoing financial and personal struggle associated with poverty and homelessness. For instance, Tony (45 years old) in Melbourne said, "Sometimes I work out there without my smiley face on. Sometimes I feel I have to be there, so 
that I can pay the bills. ... And I think as soon as you look like you're not right people notice you." Tony's reflections highlight sellers' need to use smiling as a

performative practice to attract the 'right' kind of attention. But when the

necessity to work is combined with not feeling capable of performing the 'right' kind of affective performances, sellers make difficult decisions about when to work, how long for, and importantly - when not to work. Another dimension of the shadow worlds of smiling is the possibility for negative interactions with those passing by. For instance, Harry (51 years old, London) reflected on feeling rejected when people do not return his smile. He said:

I don't mind as long as I get a smile out of them. 'Hi how are you?' and as long as I get a smile out of them. Then you get the other ones. They make out as if they can't hear me at all. I'd be like [...] 'If you can't hear me then there must be something wrong with your ears!' And they're like, no I ain't gonna look at him, I'm not going to look at him. [...] And there's other things that I sort of-I suppose it's a struggle out there when your hearts not in it or whatever. So if you're upset in any way it's not a good idea to out and sell The Big Issue. 'Cause it makes you stand out a wee bit more upset.

Similarly, in San Francisco Joel (53 years old) talked about the need to carefully construct his happiness and also manage his frustrations. He said:

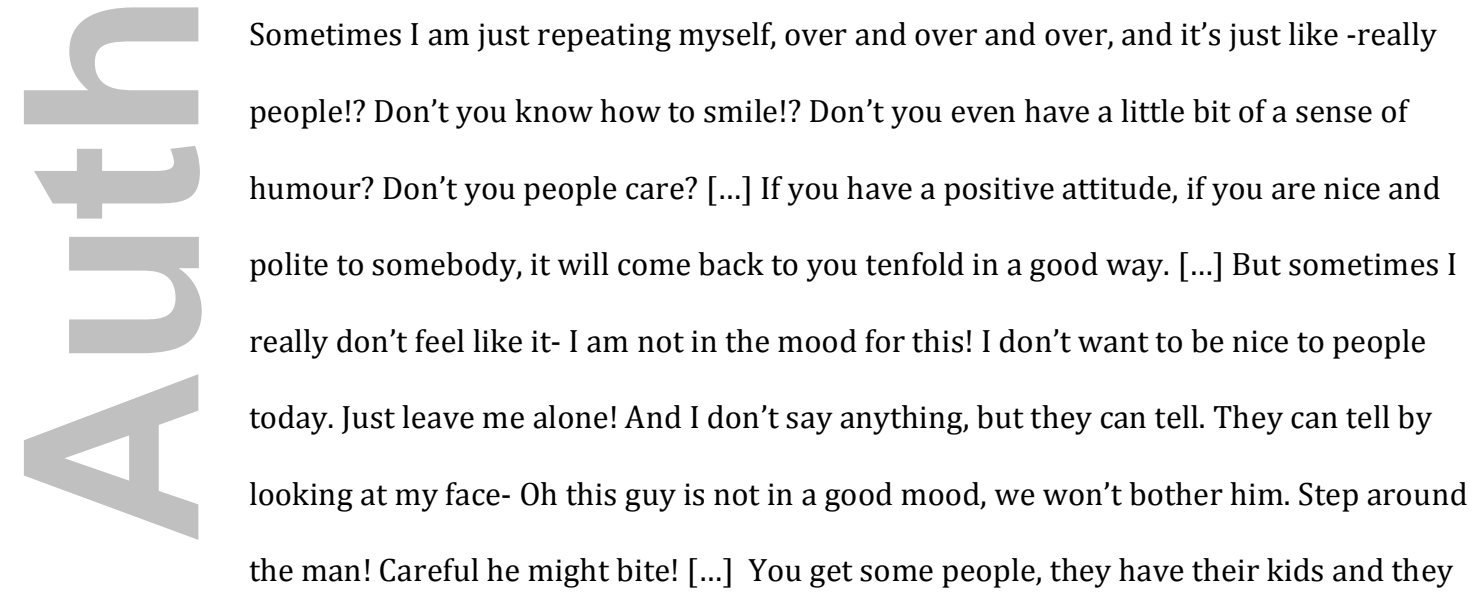


will purposefully walk their way around you or cross the street or find someway to avoid you altogether.

Cameron (forties, London) echoed Joel and Harry's reflections:

You know, when you try to make somebody smile and they give you a dirty look and look down their nose at you like you've just been scraped from the bottom of their shoe. So I've got to bite me lip and go over and grab a coffee and get it out [of] me head. Otherwise if you stay there you will end up punching somebody. Do you know what I mean? I'm just human like everybody else. It's an insult to me, especially when women walk past me and clutch their handbag like I'm going to steel their handbag or something.

Cameron, Joel and Harry point to the struggle to maintain a happy and welcoming disposition whilst also managing being ignored and purposefully avoided. In their work sellers are immediately marked out as homeless because they are selling a homeless street press. Yet they also must work to demonstrate their deservingness and enterprising spirit in spite of their homelessness and poverty. Tony, Harry, Joel and Cameron all identify the tension in the visibility required to be a successful seller. Many people passing by may recognise sellers as homeless and unemployed, but not necessarily as deserving or welcoming. Moreover, having a happy disposition is more likely to lead to the right kind of attention - the kind that translates into sales. Being upset or sad, conversely, attracts the wrong kind of attention in which abject judgements may be made about them. In the face of these negative exchanges, sellers struggle to keep up their happy and smiling dispositions, and repress their frustrations and desire to talk out or comment so as to maintain the possibility of sales.

For Gaby (33 years old, Melbourne) these challenges provoked the creation of highly enterprising management practices. Gaby creates a 
performance not just her smiling and happy disposition, but also her illness in an attempt to get sales and to attract positive judgements by people passing by.

Gaby: Now I've actually got a trait and it's spruiking [calling out to promote the magazine] and it makes people laugh, it makes me feel funny and it's good. Like the best medicine is laughter and if you can laugh at yourself, you've succeeded and that's what I do.

Researcher: So how do you make people laugh?

Gaby: I just do silly things [...] For example when [The Big Issue] office says, 'Oh you know the spring [horse] racing carnival's coming up', I make silly noises like a horse, or I pretend I'm riding a horse. [...] 'Cause as you know I have muscle spasms and seizures - I can't help it so I say, 'Come and watch my chicken dance!', that's what I call them, the chicken dance and I'm just mucking around, and people just laugh. Or if I'm not-you know how people have good days and bad days obviously anywhere? So when I have bad days, I try not to let it out in public or let myself go down too much, so I just think of positive things that I could do to turn it around to make it good. It's like being an actress. That's how I put it. I'm like an actress and I'm like, okay cover that up, who cares that you've said you're sad, angry or whatever? And so what I do is I go, no I'm not going to be depressed or angry. I mean I can be crying in the bathroom and no one will know cause I come out with a big smile on my face and I just make fun or whatever of myself or this or that and you know I just make it turn around.

Amid the pressure to accrue income, Gaby has cultivated a range of selling techniques that turn her seizures into a light-hearted event to be laughed at by people passing by. Yet, her performance 'as an actress' - as she describes it - does not come without its toll. The pressure of the performative work spills over and distresses: she must manage her feelings, taking time out of her working day to cry in the public bathroom away from the prying eyes of the public.

\section{Conclusion}


In this paper, I have sought to examine the affective dynamics of entrepreneurial and highly marginalised labour occurring in the field of unemployment. As discussed, the promise of enterprise and entrepreneurialism now has a secure place in responses to poverty and unemployment, from within the government and private sectors. Many of these initiatives extend market-based ideas of enterprise into the lives of the unemployed and poor and new modalities of ethical consumption, as markets of exchange are created whereby buyers can consume the products and services of the unemployed and poor.

Sold on city streets globally, homeless street presses are an example of both the informal economies that have emerged out of necessity and, more recently, the growth of social enterprise (particularly in the case of The Big Issue) (see Author). Homeless street press points to the material realities of poverty, and the need for informal income accrual outside of the formal employment market. They are also illustrative of contemporary cultures of care/consumption, in which acts of charity or care can be carried out in a highly individualised exchange culture, and through the purchase of commodities (see also Lindemann, 2006; Cockburn, 2014) ,

Smiles are important for homeless street press work. Selling homeless street press rests upon small affective moments of exchange: a glance; a meeting of eyes; an exchange of smiles; a moment of mutual recognition. As the analysis of sellers' accounts of their working lives reveals, sellers strive to cultivate happy and welcoming dispositions in their attempt to generate sales. Smiling is a key means by which sellers connect socially, develop feelings of worth and dignity, and attract potential buyers. Smiling is therefore woven into the practices of entrepreneurialism and deservingness that encircle this work practice. It is also 
performative in the sense that it is connected to sellers' cultivation of ways of being in their work as homeless press sellers, which requires them to be permanently 'on show' in public as they work and to commodify themselves in order to demonstrate their value and worth.

There are, therefore, shadow worlds of smiling: sellers' accounts reveal the struggle to maintain a happy disposition in the context of poverty and when faced with negative and dismissive interactions with the public as sellers' work. This work practice is ultimately framed by the structural inequalities experienced in the everyday: the frustration and feelings of shame for being unemployed; the poverty of living on welfare; and the boredom and isolation of unemployment. It is in this context that working as a seller holds its significance, and it is in this context that sellers must find ways to develop selling techniques in order to make sales and make money.

As I have outlined in this paper, this proliferating form of informal precarious work blurs the distinctions between work, charity and consumption. Here, particular forms of the self and affectivities are valorised in the act of highly precarious and marginal work. The entrepreneurial labour of homeless street press has created a highly charged affective field of commodity exchange, in which charity is personalised as an act of consumption. The relationship between buyer and seller (even if lasting just a few moments) underpins this form of labour. Homeless street press sellers craft their entrepreneurial dispositions and selling techniques in search of sales, and ultimately aim to present a version of themselves that might judged as welcoming, deserving, enterprising and worthy. Importantly, the affectivities produced in this work are done so in connection to the production, selling and consumption of the 
commodity. In this way, smiles and happy dispositions are produced in search of the image of the deserving worker and through their act of selling the magazine/paper commodity.

\section{References}

Adkins, L. (2017) Disobedient workers, the law and the making of unemployment markets, Sociology, 51:2, 290-305.

Adkins, L. (2012) Out of work or out of time? Rethinking labor after the financial crisis, South Atlantic Quarterly, 111:4, 621-641.

Back, L. (2015). Why Everyday Life Matters: Class, Community and Making Life Liveable. Sociology, 49(5), 820-836.

Barnett, C., Cloke, P., Clarke, N. and Malpass, A. (2005) Consuming ethics: articulating the subjects and spaces of ethical consumption, Antipode, 37(1): 2345.

Beechey, (2016) Social Security and the Politics of Deservingness, New York:

Palgrave Macmillan.

Centre for Charitable Giving and Philanthropy (2012) Philanthropy and

a Better Society, London: Alliance Publishing. 
Cockburn, P. J. L. (2014) Street papers, work and begging: 'experimenting' at the margins of economic legitimacy, Journal of Cultural Economy, 7:2, 145-160.

Commonwealth of Australia (2014) A new system for better employment and social outcomes: interim report of the Reference Group on Welfare Reform to the Minister for Social Services, June 2014, Canberra: Author.

Danky, J. P. \& Wiagand, W. A. (eds.) (1998) Print Culture in a Diverse America, Urbana \& Chicago: University of Illinois Press.

Dardot, P. \& Laval, C. (2014) The New Way of the World: On Neoliberal Society, London: Verso.

Dean, M. (1995) Governing the unemployed self in an active society, Economy and Society, 559-583.

Dolan, C. S. (2007) Market affections: moral encounters with Kenyan fairtrade flowers, Ethnos, 72(2): 239-261

Du Gay, P. (1996) Consumption and Identity at Work. London: Sage.

Fraser, N. \& Gordon, L. (1994) 'A genealogy of dependency: tracing a keyword of the U.S. welfare state, Signs 19(2): 309-336.

Entwistle, J. \& Wissinger, E. (2006) Keeping up apperances aesthetic labour in

the fashion modelling industries of London and New York, The Sociological Review, 54(4), 774-794.

Federici, S. (2008) Precarious labour: a feminist viewpoint, http://inthemiddleofthewhirlwind.wordpress.com/precarious-labor-a-feministviewpoint/ 
Gaber, J. (1994) Manhattan's 14th street sellers' market: informal street peddlers' complementary relationship with New York City's Economy, Urban Anthropology and Studies of Cultural Systems and World Economic Development, 23:4, 373-408. Gill, R., (2007) Technobohemians or the New Cybertariat? New Media Workers in Amsterdam a Decade after the Web, Amsterdam: The Institute of Network Cultures.

Gill, R. \& Partt, A. (2008) In the social factor? Immaterial labour, precariousness and cultural work, Theory Culture \& Society, 25(7-8): 1-30.

Gordon, E. (2013) Under-served and un-deserving: Youth empowerment programs, poverty discourses and subject formation, Geoforum, 50: 107-116.

Gray, B., Ciolfi, L., de Carvalho,?A. F. P., ? D'Andrea,? ?., Wixted, L. (2017) PostFordist reconfigurations of gender, work and life: theory and practice, British Journal of Sociology, DOI: 10.1111/1468-4446.12267.

Gowan, T. (2010) Hobos, Hustlers and Backsliders: Homeless in San Francisco,

Minneapolis: University of Minnesota Press.

Green, N. F. (1998) Chicago's Street Wise at the crossroads: a case study of a newspaper to empower the homeless in the 1990s, in J. P. Danky \& W. A. Wiagand (eds.) Print Culture in a Diverse America, Urbana \& Chicago: University of Illinois Press, pp. 34-55.

Greenslade, R. (2014) The Big Issue is used by migrants to claim benefits, says Iain Duncan Smith, The Guardian, Thursday 5 June 2014, https://www.theguardian.com/media/greenslade/2014/jun/05/the-big-issueiain-duncan-smith 
Grundy, J. \& Rundy, D. L. (2016) Deciphering deservedness: Canadian employment insurance reforms in historical perspective, Social Policy \& Administration, doi: $10.1111 /$ spol.12230.

Hibbert, S. A., Hogg, G. \& Quinn, T. (2005) Social entrepreneurship: understanding consumer motives for buying The Big Issue, Journal of Consumer Behaviour 4:3, 159-172.

Highmore, B. (2002). Everyday Life and Cultural Theory: An Introduction. London/New York: Routledge.

HM Government (2011) Growing the Social Investment Market: A Vision and Strategy, London: Author.

Hobsbawm, E. (1994). Age of Extremes. London: Abacus.

Hochschild, A. (1983) The Managed Heart: Commercialisation of Human Feeling, Twentich Anniversary Edition (2003). Berkley: University of California Press.

Humphrey, K. (2017) The accidental enterprise: Ethical consumption as commerce, Geoforum, 85: 92-100.

Kelly, P (2013) The Self as Enterprise. Furnham: Gower Publishing.

Kelly, P. and Harrison, L. (2009) Working in Jamie's Kitchen: Salvation, Passion and Young Workers. Bassingstoke, Hampshire \& New York: Palgrave Macmillan.

Li, V. (2017) 'Shopping for Change': World Vision Canada and Consumption-

Oriented Philanthropy in the Age of Philanthrocapitalism, VOLUNTAS: International Journal of Voluntary and Nonprofit Organizations, 28(2): 455-471. 
Lindemann, K. (2006) A tough sell: stigma as souvenir in the contested performances of San Francisco's homeless Street Sheet vendors, Text and

Performance Quarterly 27(1): 41-57.

Llewellyn, N. \& Burrow, R. (2008) Streetwise sales and the social order of city streets, The British Journal of Sociology 59(3), 561-583.

Minnery, J., \& Greenhalgh, E. (2003). Approaches to Homelessness Policy in Europe, the United States and Australia. Journal of Social Issues, 63(3), 641-655.

Mittelman, R. \& Rojas-Méndez, J. I. (2013) Exploring consumer's needs and motivations in online social lending for development, Journal of Nonprofit \& Public Sector Marketing, 25(4): 309-333.

Morini, C. \& Fumagilli, A. (2010) Lift put to work: towards a life theory of value, Ephemera 10(3/4): 234-252.

Morris, A. \& Wilson, S. (2014) Struggling on the Newstart unemployment benefit in Australia: The experience of a neoliberal form of employment assistance, The Economic and Labour Relations Review, 25(2): 202-221.

Murtola, A. (2014) Experience, commodification, biopolitics, Critical Sociology, $40(6) 835-854$.

Nagel, C. \& Ehrkamp, P. (2016) Deserving welcome? Immigrants, Christian faith communities, and the contentious politics of belonging in the US South, Antipode, $48: 4,1040-1058$. 
Peel, M. (2012) Miss Cutler and the Case of the Resurrected Horse: Social Work and the Story of Poverty in America, Australia and Britain. Chicago \& London:

University of Chicago Press.

Peel, M. (2003). The Lowest Rung: Voices of Australian Poverty. Cambridge:

Cambridge University Press.

Penman, D. (1994) 'Big Issue' editor will not give names: Homeless people feel victimised by officials who are targeting the magazine which is their lifeline, The Independent, Wednesday 21 September 1994,

http://www.independent.co.uk/news/uk/big-issue-editor-will-not-give-nameshomeless-people-feel-victimised-by-officials-who-are-targeting-1450300.html

Rose, N. (1989) Governing the Soul: The Shaping of the Private Self, London: Routledge.

Roy, A. (2010) Poverty Capital: Microfinance and the Making of Development, New York: Routledge.

Scharff, C. (2016) 'The psychic life of neoliberalism: Mapping the contours of entrepreneurial subjectivity', Theory, Culture \& Society 33(6): 107-122.

Seabrook, J. (2013) Pauperland: A Short History of Poverty in Britain, London: C.

\section{Hurst \& Co.}

Signalla, R. J. \& Carney, S. (2012) Poverty reduction through entrepreneurship: microcredit, learning and ambivalence amongst women in urban Tanzania, International Journal of Educational Development, 32, 546-554. 
Skeggs, B. \& Loveday, V. (2012) Struggles for value: value practices, injustice, judgment, affect and the idea of class, British Journal of Sociology, 63(3): 472-490.

Taylor, S. (2015) A new mystique? Working for yourself in the neoliberal economy, The Sociological Review, 63(S1), 174-187.

Teasdale, S. (2010) Models of social enterprise in the homelessness field, Social Enterprise Journal, 6(1): 23-34

Tyler, M. (2012) Working in the other Square Mile: performing and placing sexualized labour in Soho's sex shops, Work, Employment and Society, 26(6): 899-917.

Villadsen, K. (2011) Modern welfare and 'good old' philanthropy, Public Management Review 13(8): 1057-1075.

Weeks, K. (2007) Life within and against work: affective labour, feminist critique and post-fordist politics, Ephemera, 7(1): 233-249.

Williams, C. (2003) Sky service: the demands of emotional labour in the airline industry, Gender, Work \& Organization, 10(5): 513-550.

Williams, C. C. \& Nadin, S. (2010) Rethinking the commercialization of everyday life: a "whole economy" perspective, foresight, 12(6), 55-68.

Zizek, S. (2009) First as Tragedy Then as Farce. London: Verso. 


\section{University Library}

\section{- M M I N E R VA A gateway to Melbourne's research publications}

Minerva Access is the Institutional Repository of The University of Melbourne

Author/s:

Gerrard, J

Title:

The economy of smiles: affect, labour and the contemporary deserving poor

Date:

2019-03-01

Citation:

Gerrard, J. (2019). The economy of smiles: affect, labour and the contemporary deserving poor. BRITISH JOURNAL OF SOCIOLOGY, 70 (2), pp.424-441. https:// doi.org/10.1111/1468-4446.12350.

Persistent Link:

http://hdl.handle.net/11343/283884 